\title{
Pengaruh Pendekatan Konstruktivisme terhadap Hasil Belajar IPA di Kelas V SDN 33 Kalumbuk Kota Padang
}

\section{Adriantoni $^{1}$ Altika Syafitri²}

1 STKIP Adzkia, Kota Padang, Indonesia, Email: adriantoni804@gmail.com

2 STKIP Adzkia, Kota Padang, Indonesia, Email: altikasyafitri96@gmail.com

\begin{abstract}
ABSTRAK
Penelitian ini bertujuan untuk mengetahui pengaruh penggunaan pendekatan konstruktivisme terhadap hasil belajar IPA di kelas V SDN 33 Kalumbuk Kota Padang tahun ajaran 2017/2018. Populasi penelitian ini adalah peserta didik kelas V SDN 33 Kalumbuk Kota Padang dan sampel dari populasi dilakukan secara acak tanpa memperhatikan starata yang ada dalam populasi. Teknik penentuan sampel secara jenuh dengan rancangan penelitian posttest only control design. Pengumpulan data dalam penelitian ini adalah menggunakan tes hasil belajar berupa soal objektif sebanyak 16 butir soal, data yang diperoleh dianalisis dengan menggunakan uji t. Berdasarkan hasil penelitian ini,terlihat bahwa $t_{\text {hitung }}=1,9252$ dan $t_{\text {tabel }}=1,692$ dan taraf signifikan 5\%. Berdasarkan pengujian $t_{\text {hitung }}>t_{\text {tabel }}(1,9252>1,692)$ maka hipotesis atau $\mathrm{H}_{1}$ diterima. Dari hasil penelitian terbukti bahwa penggunaan pendekatan konstruktivismememberikan pengaruh terhadap hasil belajar IPA di kelas V SDN 33 Kalumbuk kota Padang tahun ajaran $2017 / 2018$.

Kata Kunci: Pengaruh, Pendekatan Konstruktivisme, Hasil Belajar IPA
\end{abstract}

\begin{abstract}
This study aims to determine the effect of the use of the constructivism approach to science learning outcomes in the fifth grade of SDN 33 Kalumbuk, Padang City $2017 / 2018$ academic year. The population of this study were fifth grade students of SDN 33 Kalumbuk, Padang City and samples from the population were randomly carried out without regard to the starata in the population. Saturated sample determination technique with posttest only control design study design. Data collection in this study is to use test results in the form of objective questions as many as 16 items, the data obtained were analyzed using the t test. Based on the results of this study, it can be seen that 1.9252 and $=1.692$ and a significant level of $5 \%$. Based on testing $>(1,9252>1,692)$ then the hypothesis or H1 is accepted. From the results of the study it is proven that the use of a constructivist approach provides an influence on the learning outcomes of science in the fifth grade of SDN 33 Kalumbuk, Padang city in the academic year 2017/2018.

Keywords: Influence, Contructivism Approach, the Results of Learning Science.
\end{abstract}




\section{PENDAHULUAN}

Penelitian ini dilatar belakangi oleh beberapa alasan, di antaranya guru belum sepenuhnya memfasilitasi peserta didik dengan menggunakan pendekatan pembelajaran yang dapat menciptakan peserta didik aktif dalam belajar. Hal tersebut terlihat dari aspek peserta didik 1) kurangnya partisipasi peserta didik dalam belajar, 2) kurangnya rasa tanggung jawab terhadap tugas yang diberikan oleh guru, 3) peserta didik belum dibiasakan dalam berdiskusi kelompok, 4) peserta didik belum mampu mengembangkan pengetahuan baru secara aktif, 5) peserta didik belum mampu mengembangkan kemampuan berpikir kritis dalam proses pembelajaran, 6) peserta didik belum dihadapkan pada keadaan yang menimbulkan konflik di dalam pikiran peserta didik, 7) peserta didik belum dihadapkan dalam pemecahan masalah saat proses pembelajaran. 8) guru belum menciptakan iklim pembelajaran yang memungkinkan peserta didik dapat mengaplikasikan pemahaman faktualnya, 9) guru belum mampu membangun interpretasi peserta didik berdasarkan pengalaman belajar. Sehingga permasalahan tersebut berdampak pada hasil belajar peserta didik jadi rendah,dapat dilihat pada Tabel 1 berikut ini :

Tabel. 1 Nilai Ulangan Harian Peserta didik Kelas V SDN 33 Kota Padang

\begin{tabular}{|c|c|c|c|c|}
\hline Kls & $\begin{array}{c}\text { Jml } \\
\text { Peser } \\
\text { ta } \\
\text { didik }\end{array}$ & $\begin{array}{c}\text { Jml } \\
\text { Peserta } \\
\text { didik } \\
\text { yang } \\
\text { Tuntas } \\
\text { (KKM } \geq \\
\text { 80) }\end{array}$ & $\begin{array}{l}\text { Rata } \\
\text {-rata } \\
\text { Nilai }\end{array}$ & $\begin{array}{c}\text { Persen } \\
\text { tase } \\
\text { Ketun } \\
\text { tasan }\end{array}$ \\
\hline V A & 16 & 7 & 78 & $56 \%$ \\
\hline V B & 20 & 9 & 80 & $55 \%$ \\
\hline
\end{tabular}

Sumber: Guru dan tata usaha SDN 33 Kota Padang

Berdasarkan tabel I di atas dapat dilihat bahwa hasil nilai Ulangan Harian Semester I IPA Peserta didik Kelas V SDN 33 Kota Padang Tahun Ajaran 2017/2018 belum tuntas. Jumlah ketuntasan berada dibawah kriteria ketuntasan minimal (KKM) yang ditetapkan sekolah untuk mata pelajaran IPA yakni 80. Pembelajaran merupakan proses interaksi antara guru dengan peserta didik. Menurut Wina Sanjaya (2010:216) sebagai suatu interaksi antara guru dan peserta didik pembelajaran memiliki tiga karakteristik: 1) pembelajaran 
adalah proses berfikir, 2) proses pembelajaran adalah memanfaatkan potensi otak dan 3) pembelajaran berlangsung sepanjang hayat. Dari hasil nilai peserta didik tersebut menunjukkan bahwa dalam proses pembelajaran IPA perlu diperbaiki, agar dapat meningkatkan hasil belajar IPA peserta didik kelas V SDN 33 Kota Padang. Fokus dari penelitian ini adalah bagaimana pengaruh pendekatan konstruktivisme terhadap hasil belajar IPA di kelas V SDN 33 Kota Padang.

Oleh karena itu, supaya hasil belajar IPA peserta didik tuntas atau di atas KKM, peneliti ingin memvariasikan strategi pembelajaran yang berbeda dari strategi pembelajaran yang diterapkan oleh guru kelas. Untuk menerapkan proses pembelajaran harus menggunakan pendekatan dengan harapan agar hasil belajar yang didapatkan oleh peserta didik lebih baik dari pada hasil belajar peserta didik yang tidak menggunakan pendekatan pembelajaran. Salah satu cara untuk meningkatkan hasil belajar IPA peserta didik yaitu dengan mengaitkan pembelajaran IPA dengan dunia nyata peserta didik secara langsung dengan menggunakan pendekatan konstruktivisme. Karena dengan menggunakan pendekatan konstruktivisme inilah hasil belajar IPA peserta didik dapat meningkat, sebab salah satu kelebihan konstruktivisme adalah peserta didik mengkonstruksi pengetahuan dengan cara mengintegrasikan ide yang mereka miliki dan pembelajaran lebih bermakna karena peserta didik mengerti.

Menurut Trianto (2014:74), "Pendekatan konstruktivisme dalam pengajaran menerapkan pembelajaran kooperatif secara intensif, atas dasar teori bahwa peserta didik akan lebih mudah menemukan dan memahami konsep-konsep yang sulit apabila mereka dapat saling mendiskusikan masalah-masalah itu dengan temannya". Selanjutnya menurut Suyono dan Hariyanto (2013:108109), mengatakan kelebihan dari pendekatan konstruktivisme yaitu: “(1) peserta didik mengkonstruksi pengetahuan dengan cara mengintegrasikan ide yang mereka miliki, (2) pembelajaran lebih bermakna karena peserta didik 
mengerti, (3) strategi peserta didik sendiri lebih bernilai, dan (4) peserta didik mempunyai kesempatan untuk berdiskusi dan saling bertukar pengalaman dan pengetahuan dengan temannya".

Implementasi pendekatan konstruktivisme dalam pembelajaran meliputi 4 tahap yaitu: (1) apersepsi, (2) eksplorasi, diskusi dan penjelasan konsep dan (4) pengembangan dan aplikasi sebagaimana Suwangsih (2006:116) menjelaskan (1) Tahap pertama (apersepsi), guru mendorong peserta didik untuk berani menyampaikan konsep tentang materi yang dipelajari. Selanjutnya, guru juga diminta untuk memancing memberikan pertanyaan-pertanyaan tentang fenomena yang sering ditemui sehari-hari dengan mengaitkan konsep yang akan dibahas. (2) Tahap kedua (eksplorasi), peserta didik diberi kesempatan untuk menyelidiki dan menemukan konsep pengumpulan, pengorganisasian, dan penginterpretasian data dalam suatu kegiatan yang telah dirancang guru. Kemudian secara berkelompok didiskusikan dengan kelompok lain. (3) Tahap ketiga (diskusi dan penjelasan konsep) saat peserta didik memberikan penjelasan dan solusi yang didasarkan pada hasil observasinya ditambah dengan penguatan dari guru. (4) Tahap keempat (pengembangan dan aplikasi) guru berusaha menciptakan iklim pembelajaran yang memungkinkan peserta didik dapat mengaplikasikan pemahaman konseptualnya, baik melalui kegiatan atau pemunculan dan pemecahan masalah-masalah yang berkaitan dengan isu-isu di lingkungannya.

Penelitian

mengenai

pendekatan konstruktivisme bukanlah penelitian yang pertama melainkan sudah pernah dilakukan oleh peneliti sebelumnya. Penulis melakukan penelitian kembali mengenai pendekatan konstruktivisme karena model pembelajaran tersebut terbukti dapat meningkatkan hasil belajar peserta didik pada penelitian sebelumnya. Berikut penelitianpenelitian yang mengkaji tentang pendekatan konstruktivisme.

Penelitian yang dilakukan oleh Siti Rahmina Haerunisa (2008:26), yang berjudul "Pengaruh Pembelajaran Konstruktivisme 
dalam Pembelajaran Kimia Terhadap Pemahaman Konsep Peserta didik Tentang Sistem Koloid (Penelitian Tindakan Kelas di MA AlBaqiyatusholihat Tenjo Bogor)". Penelitian dilakukan pada tanggal 17 Maret-18 April 2008, hasil penelitiannya menyimpulkan bahwa penerapan pembelajaran konstruktivisme dapat meningkatkan aktivitas dan prestasi belajar peserta didik.

Penelitian yang dilakukan oleh Eka Jasumayanti (2013:29), dalam skripsinya yang berjudul "Korelasi antara Pendekatan Konstruktivisme dengan Hasil Belajar Peserta didik Pada Pembelajaran IPS SD" membuktikan bahwa penerapan pendekatan konstruktivis mememberikan pengaruh yang positif dalam kegiatan belajar peserta didik padapelajaran IPS. Penelitian yang dilakukan Jasumayanti (2013) memiliki kesamaan pada pendekatan konstruktivisme yang digunakan untuk mengetahui hubungan dan pengaruh dengan hasil belajar IPS peserta didik.

Muhammad Hasan Sidik (2012:30), dalam skripsinya yang berjudul "Penerapan Model
Pembelajaran Konstruktivisme untuk Meningkatkan Pemahaman Peserta didik Mengenai Energi Gerak di Kelas III SD Negeri I Cilengkranggirang Kecamatan Pasaleman Kabupaten Cirebon", menyimpulkan bahwa dengan menggunakan pendekatan konstruktivisme dapat meningkatan tentang pemahaman peserta didik pada mata pelajaran IPA.

Beberapa penelitian mengenai pendekatan konstruktivisme yang telah dilakukan menunjukkan pendekatan pembelajaran ini mampu meningkatkan pembelajaran, maka peneliti mengambil penelitian ini untuk melihat pengaruh pendekatan konstruktivisme terhadap hasil belajar peserta didik pada mata pelajaran IPA di kelas V SDN 33 Kota Padang.

Tujuan dari penelitian ini yaitu untuk mengetahui pengaruh pendekatan konstruktivisme terhadap hasil belajar IPA di kelas V SDN 33 Kota Padang.

\section{METODE}

Pendekatan yang digunakan dalam penelitian ini adalah kuantitatif, dengan menggunakan 
desain Quasi Experimental

normalitas

untuk

lebih

Rancangan yang digunakan adalah mengakuratkan data. Data dikatakan Posttes Only Control Design. normal apabila nilai signifikansi lebih Rancangan penelitian Posttes Only besar dari 0,05 (Priyatno, 2010: 71).

Control Design dapat dilihat pada tabel 2 berikut:

Tabel 2. Rancangan penelitian

Posttes Only Control Design

\begin{tabular}{ccc}
\hline Kelas & Perlakuan & Posttest \\
\hline Eksperimen & $\mathbf{X}$ & $\mathbf{O}$ \\
\hline Kontrol & - & $\mathbf{O}$
\end{tabular}

Sumber: Sugiyono, (2011:112)

Keterangan:

$\mathrm{X}=$ Perlakukan yang diberikan pada kelas eksperimen, dengan mengunakan pendekatan konstruktivisme.

$\mathrm{O}=$ Tes akhir yang diberikan pada kelas eksperimen dan kelas kontrol.

- $\quad=$ Tidak diberikan perlakuan pada kelas kontrol

Teknik pengumpulan data yang penulis lakukan yaitu berbentuk tes.

Analisis Data yang dilakukan dalam penelitian ini yaitu:

\section{A. Uji Normalitas}

Dalam penelitian ini, teknik pengujian normalitas data dilakukan menggunakan uji Liliefors dengan melihat nilai signifikansi pada kolomogorov-Smirnov. Pada penelitian ini, penulis menggunakan Software SPSS 21, dalam melakukan uji

\section{B. Uji Homogenitas}

Uji homogenitas data dalam penelitian ini dilakukan dengan uji levene menggunakan bantuan program SPSS versi 21. Dalam data penelitian yang telah diuji homogenitasnya dengan menggunakan aplikasi software SPSS maka didapatkan data yang berdistribusi homogen.

\section{Uji Hipotesis}

Peneliti ingin melihat pengaruh hasil belajar peserta didik yang menggunakan pendekatan kontruktivisme sebagai kelompok eksperimen dan kelompok kontrol. Hipotesis yang dikemukakan:

$H_{0}: \mu_{1}=\mu_{2}$ Tidak terdapat pengaruh penggunaan pendekatan konstruktivisme terhadap hasil belajar IPA dikelas V SDN 33 Kota Padang.

$$
H_{1}: \mu_{1}>\mu_{2} \text { Terdapat pengaruh }
$$
penggunaan pendekatan konstruktivisme terhadap hasil belajar IPA dikelas V SDN 33 Kota Padang. 
Dimana $\mu_{1}$ merupakan ratarata hasil belajar IPA peserta didik kelas eksperimen dan $\mu_{2}$ merupakan rata-rata hasil belajar IPA kelas kontrol.

Penulis menggunakan uji $\mathrm{t}$ untuk pengujian hipotesis apabila data berdistribusi normal dan mempunyai variansi homogen.

Rumus uji $\mathrm{t}$ adalah sebagai berikut:

$$
\begin{aligned}
& t=\frac{\overline{X_{1}}-\overline{X_{2}}}{s \sqrt{\frac{1}{n_{1}}+\frac{1}{n_{2}}}} \text { Dengan } \\
& S=\sqrt{\frac{\left(n_{1}-1\right) s_{1}^{2}+\left(n_{2}-1\right) s_{2}^{2}}{n_{1}+n_{2}-2}}
\end{aligned}
$$

Dimana:

$\overline{X_{1}}=$ Nilai rata-rata kelas eksperimen

$\overline{X_{2}}=$ Nilai rata-rata kelas kontrol

$\mathrm{S} \quad=$ Standar deviasi kedua kelas sampel

$S_{1}^{2} \quad=$ Variansi kelas eksperimen

$S_{2}^{2} \quad=$ Variansi kelas kontrol

$\mathrm{n}_{1}=$ Jumlah peserta didik kelas eksperimen

$\mathrm{n}_{2}=$ Jumlah peserta didik kelas kontrol

Keputusannya: $\mathrm{H}_{1}$ diterima dengan $t_{\text {hitung }}>\mathrm{t}_{\text {tabel }}$ di mana $t_{1-} \alpha$ didapat dari daftar distribusi $t$ dengan $\mathrm{dk}=\mathrm{n}_{1}+\mathrm{n}_{2}-2$. Harga $\mathrm{t}$ lainnya $\mathrm{H}_{0}$ ditolak (Sudjana, 2002:39).

III. HASIL DAN PEMBAHASAN

\section{A. Hasil}

\section{Deskripsi Data}

Penelitian ini merupakan penelitian kuantitatif dengan rancangan penelitian "Posttest Only Design", menempatkan subjek penelitian ke dalam dua kelas, yaitu kelas eksperimen dan kelas kontrol. Kelas eksperimen diberi perlakuan dengan menggunakan pendekatan konstruktivisme sedangkan padakelas kontrol menggunakan pembelajaran konvensional. Sebagaimana dijelaskan pada babbab sebelumnya. Data yang diperoleh dalam penelitian ini adalah data nilai hasil tes akhir berupa soal pilhan ganda sebanyak 16 soal pada mata pelajaran IPA di kelas V SD Negeri 33 Kota Padang. Jumlah peserta didik pada kelas eksperimen sebanyak 16 orang, dan mengikuti tes akhir keseluruhannya. Pada kelas kontrol jumlah peserta didiknya 20 orang dan yang mengikuti tes akhir sebanyak 19 orang.

Kelas yang diambil untuk penelitian yaitu kelas VA dan kelas 
VB, kelas VA sebagai kelas eksperimen dan kelas VB sebagai kelas kontrol, masing-masing kelas terdiri atas tiga kali pertemuan yaitu sebagai berikut:

\section{a. Pertemuan Kelas Eksperimen}

\section{Pertemuan Satu}

1) Tahap Persiapan

Pelaksanaan pembelajaran menggunakan pendekatan konstruktivisme di kelas VA atau kelas eksperimen dilaksanakan pada hari Rabu tanggal 28 Februari 2018. Sebelum memulai pembelajaran guru terlebih dahulu menyiapkan materi yang akan dipelajari serta media pembelajaran yang akan digunakan oleh guru dalam proses pembelajaran berlangsung.

2) Pelaksanaan Pembelajaran

Setelah guru menyiapkan materi yang akan dipelajari guru memulai pembelajaran dengan kegiatan awal yang dilakukan guru dalam proses pembelajaran yaitu membuka pembelajaran dengan salam, mengkondisikan kelas, pembacaan doa, mengecek kehadiran peserta didik, dan mempersiapkan materi ajar serta alat peraga. Sebelum proses pembelajaran dimulai guru terlebih

dahulu menyampaikan tujuan pembelajaran yang ingin dicapai peserta didik dan memotivasi peserta didik dalam proses belajar serta guru mengajukan beberapa pertanyaan tentang daur air. Untuk mengetahui pengetahuan awal peserta didik tentang daur air yang akan dipelajari.

Kegiatan inti yang terdiri atas tahap eksplorasi, guru melakukan tanya jawab dengan menggali pengetahuan peserta didik dengan mengajukan beberapa pertanyaan tentang daur air untuk mengetahui pengetahuan awal peserta didik dan guru memperlihatkan sebuah gambar tentang daur air. Sambil melakukan tanya jawab tentang proses terjadinya daur air. Tahap elaborasi, peserta didik diminta untuk memperhatikan guru menjelaskan konsep tentang proses daur air sebelumnya guru telah memperlihatkan sebuah gambar terjadinya proses daur air. Peserta didik diminta untuk memperhatikan proses terjadinya daur air. Daur air merupakan sirkulasi (perputaran) air secara terus-menerus dari bumi ke atmosfer dan kembali ke Bumi. Daur air ini terjadi melalui proses evaporasi (penguapan), presipitasi 
(pengendapan), dan kondensasi (pengembunan). Setelah selesai guru dan peserta didik melakukan tanya jawab dan membarikan kesempatan kepada peserta didik untuk bertanya.

Pada tahap konfirmasi, setelah beberapa peserta didik yang telah mengajukan pertanyaan guru dan peserta didik melakukan tanya jawab untuk menjawabnya, setelah selesai guru meminta salah satu peserta didik untuk dapat menyimpulkan materi yang telah dipelajari. Setelah peserta didik selesai menyimpulkan guru memberikan penguatan dari kesimpulan yang diberikan peserta didik. Kegiatan akhir pada pembelajaran yaitu sebelum guru menutup pelajaran dengan membaca do'a terlebih dahulu guru memberikan LKS kepada peserta didik, setelah selesai mengerjakan LKS baru guru menutup pembelajaran dengan membaca do'a belajar dan salam.

\section{Pertemuan Kedua}

1) Tahap Persiapan

Selanjutnya pertemuan kedua yang dilaksanakan pada hari Kamis tanggal 1 Maret 2018 di kelas VA atau kelas eksperimen dengan menggunakan pendekatan konstruktivisme. Sebelum memulai pembelajaran guru terlebih dahulu menyiapkan materi yang akan dipelajari serta media pembelajaran yang akan digunakan oleh guru dalam proses pembelajaran berlangsung.

2) Pelaksanaan Pembelajaran

Setelah guru menyiapan materi yang akan dipelajari guru memulai pembelajaran dengan kegiatan awal yang dilakukan dalam proses pembelajaran yaitu membuka pembelajaran dengan salam, mengkondisikan kelas, pembacaan do'a, mengecek kehadiran peserta didik, dan mempersiapkan materi ajar serta media pembelajaran yang akan digunakan. Sebelum proses pembelajaran dimulai guru terlebih dahulu menyampaikan tujuan pembelajaran yang ingin dicapai peserta didik dan memotivasi peserta didik dalam proses belajar serta guru mengajukan beberapa pertanyaan tentang kegiatan manusia yang mempengaruhi daur air. Untuk mengetahui pengetahuan awal peserta didik tentang kegiatan manusia yang mempengaruhi daur air yang akan dipelajari. 
Kegiatan inti yang terdiri atas tahap eksplorasi, guru melakukan tanya jawab dengan menggali pengetahuan peserta didik dengan mengajukan beberapa pertanyaan tentang kegiatan manusia yang mempengaruhi daur air untuk mengetahui pengetahuan awal peserta didik, dan guru mempersiapkan peserta didik untuk memperhatikan guru dengan menggunakan media gambar tentang kegiatan manusia yang mempengaruhi daur air yang telah disiapkan oleh guru. Tahap elaborasi, peserta didik diminta untuk memperhatikan guru menjelaskan konsep tentang kegiatan manusia yang mempengaruhi daur air. Setelah itu guru dan peserta didik melakukan tanya jawab, dan memberikan kesempatan pada peserta didik untuk bertanya.

Pada tahap konfirmasi, setelah beberapa peserta didik yang telah mengajukan pertanyaan kepada guru, guru dan peserta didik melakukan tanya jawab untuk menjawabnya, setelah selesai guru meminta salah satu peserta didik untuk dapat menyimpulkan materi yang telah dipelajari. Setelah peserta didik selesai menyimpulkan guru memberikan penguatan dari kesimpulan yang diberikan peserta didik. Kegiatan akhir pada pembelajaran yaitu guru memberikan LKS kepada peserta didik, setelah selesai mengerjakan LKS baru guru menutup pembelajaran dengan membaca do'a belajar dan salam.

\section{b. Pertemuan Kelas Kontrol}

\section{Pertemuan Satu}

1) Tahap Persiapan

Pelaksanaan pembelajaran dengan menerapkan pembelajaran konvensional di kelas VB atau kelas kontrol dalam penelitian ini dilaksanakan pada hari Rabu tanggal 28 Februari 2018. Sebelum memulai pembelajaran guru terlebih dahulu menyiapkan materi yang akan dipelajari dalam proses pembelajaran berlangsung.

2) Pelaksanaan Pembelajaran

Setelah guru menyiapkan materi yang akan dipelajari guru memulai pembelajaran dengan kegiatan awal yang dilakukan guru dalam proses pembelajaran yaitu membuka pembelajaran dengan salam, mengkondisikan kelas, pembacaan doa, mengecek 
kehadiran peserta didik, dan

melakukan tanya jawab untuk mempersiapkan materi ajar. menjawabnya, setelah selesai guru Sebelum proses pembelajaran dimulai guru terlebih dahulu menyampaikan tujuan pembelajaran yang ingin dicapai peserta didik dan memotivasi peserta didik dalam proses belajar serta guru mengajukan beberapa pertanyaan tentang proses terjadinya daur air. Untuk mengetahui pengetahuan awal peserta didik tentang daur air.

Pada kegiatan inti, peserta didik mendengarkan penjelasan guru tentang proses terjadinya daur air dan melakukan tanya jawab. Tahap elaborasi, guru menyampaikan materi pembelajaran kepada peserta didik secara konvensional dan tanya jawab tentang materi daur air. Tahap konfirmasi guru menjelaskan kembali secara ringkas mengenai materi yang dipelajari. Guru memberikan kesempatan pada peserta didik untuk bertanya dan melakukan tanya jawab mengenai pertanyaan-pertanyaan yang diberikan.

Pada tahap konfirmasi, setelah beberapa peserta didik yang telah mengajukan pertanyaan kepada guru, guru dan peserta didik 
dengan salam, mengkondisikan kelas, mengecek kehadiran peserta didik yang mengikuti pembelajaran, selanjutnya guru menyampaikan tujuan pembelajaran, dan memotivasi peserta didik dalam proses belajar.

Pada kegiatan inti, peserta didik mendengarkan penjelasan guru tentang kegiatan manusia yang mempengaruhi daur air dan melakukan tanya jawab. Tahap elaborasi, guru menyampaikan materi pembelajaran kepada peserta didik secara konvensional dan tanya jawab tentang materi kegiatan manusia yang mempengaruhi daur air. Tahap konfirmasi guru menjelaskan kembali secara ringkas mengenai materi yang dipelajari. Guru memberikan kesempatan pada peserta didik untuk bertanya dan melakukan tanya jawab mengenai pertanyaan-pertanyaan yang diberikan.

Pada tahap konfirmasi, setelah beberapa peserta didik yang telah mengajukan pertanyaan kepada guru, guru dan peserta didik melakukan tanya jawab untuk menjawabnya, setelah selesai guru meminta salah satu peserta didik untuk dapat menyimpulkan materi

yang telah dipelajari. Setelah peserta didik selesai menyimpulkan guru memberikan penguatan dari kesimpulan yang diberikan peserta didik. Kegiatan akhir pada pembelajaran yaitu sebelum guru menutup pelajaran dengan membaca do'a terlebih dahulu guru memberikan LKS kepada peserta didik, setelah selesai mengerjakan LKS baru guru menutup pembelajarandengan membaca do'a belajar dan salam.

\section{c. Pemberian Test Hasil Belajar}

Tahap Penyelesaian

Pertemuan selanjutnya pada hari Jumat 2 Maret 2018, guru memberikan tes akhir berupa soal pilihan ganda sebanyak 16 butir pada kelas eksperimen dan kelas kontroldengan tujuan untuk melihat hasil belajar peserta didik. Setelah hasil tes diperoleh maka dilanjutkan dengan menganalisis data tes akhir tersebut.

\section{Pengujian Persyaratan Analisis}

Berdasarkan penelitian yang telah dilakukan pada kedua kelas sampel, maka diperoleh data mengenai hasil belajar peserta didik pada pembelajaran IPA materi daur 
air dan kegiatan manusia yang mempengaruhinya. Data diperoleh melalui tes akhir yang dilakukan pada akhir penelitian, soal tes akhir berupa soal pilihan ganda sebanyak 16 butir soal. Soal tes akhir sebanyak 16 butir soal tersebut diperoleh dari soal 30 butir soal yang telah diuji cobakan pada SDN 05 Kota Padang. Setelah diuji cobakan pada SDN 05 Kota Padang, dicari indeks kesukaran dan daya beda dengan menggunakan aplikasi Microsoff Excel. Setelah diketahui hasil dari indeks kesukaran dan daya beda yang diolah dengan aplikasi Microsoff Excell, maka diperoleh 16 butir soal yang akan dijadikan soal tes akhir di SDN 33 Kota Padang. Jumlah peserta didik pada kelas eksperimen sebanyak 16 orang, dan mengikuti tes akhir keseluruhannya dan pada kelas kontrol 20 orang, yang mengikuti tes akhir sebanyak 19 orang.

Data perolehan hasil belajar peserta didik pada materi daur air dan kegiatan manusia yang mempengaruhinya dapat dilihat dari hasil tes akhir setelah diberikan perlakuan dengan menggunakan pendekatan konstruktivisme pada kelas eksperimen dan pada kelas

kontrol menggunakan pembelajaran konvensional. Dari tes akhir diperoleh nilai rata-rata $(\bar{x})$, simpangan baku $(S)$, nilai tertinggi $\left(x_{\text {maks }}\right)$ nilai terendah $\left(x_{\min }\right)$ terlihat pada Tabel berikut:

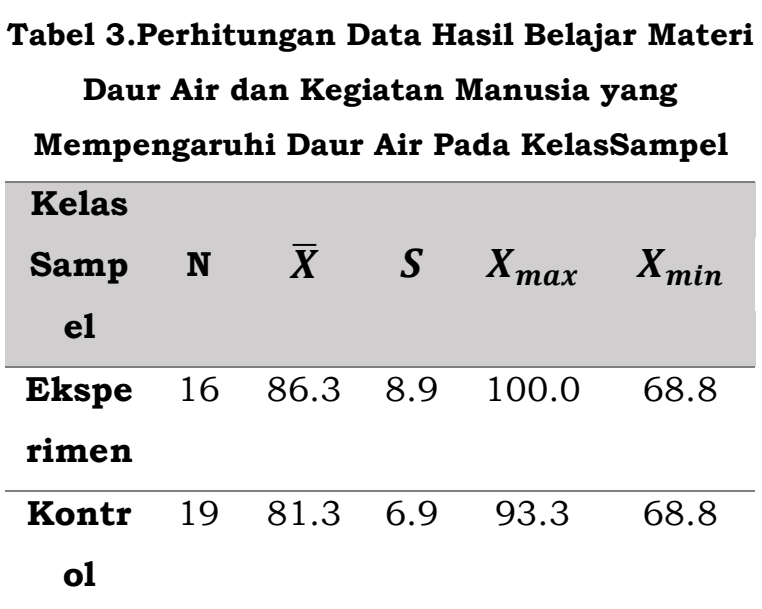

Pada Tabel 1 terlihat bahwa rata-rata hasil belajar IPA pada materi daur air dan kegiatan manusia yang mempengaruhinya pada kelas eksperimen lebih tinggi dari pada rata-rata hasil belajar materi daur air dan kegiatan manusia yang mempengaruhinya pada kelas kontrol. Selanjutnya perolehan nilai tertinggi dan terendah antara kelas eksperimen dan kelas kontrol memiliki nilai yang berbeda, nilai tertinggi peserta didik pada kelas eksperimen $x_{\text {maks }}=100$ lebih tinggi dari pada kelaskontrol $x_{\text {maks }}=93,3$ demikian pula jika dilihat dari nilai terendah yang 
diperoleh peserta didik pada kelas eksperimen $x_{\min }=68$, sama dengan kelas control $x_{\min }=68$.

Tujuan analisis data pada penelitian ini adalah untuk mengetahui apakah hasil belajar peserta didik pada materi daur air dan kegiatan manusia yang mempengaruhinya dengan menggunakan pendekatan konstruktivisme lebih baik daripada hasil belajar peserta didik pada materi daur air dan kegiatan manusia yang mempengaruhinya dengan pembelajaran konvensional pada kelas V SDN 33 Kota Padang. Selanjutnya, menguji hipotesis sebelum menarik kesimpulan, terlebih dahulu data yang dikumpulkan untuk dianalisis. Uji hipotesis yang digunakan adalah uji $t$ syarat penggunaan uji-t bahwa data harus berasal dari populasi yang berdistribusi normal dan homogen dengan mengunakan aplikasi SPSS 21 sebagai berikut:

\section{a. Uji Normalitas Tes Akhir}

Hasil uji normalitas yang diperoleh dapat dilihat pada Tabel di berikut ini:

Tabel 4. Hasil Uji Normalitas Tes Hasil Belajar Materi Daur Air dan Kegiatan Manusia yang Mempengaruhinya Kelas Sampel

\begin{tabular}{|ll|c|c|c|c|c|c|}
\hline \multirow{2}{*}{ Kelas } & \multicolumn{3}{|c|}{$\begin{array}{l}\text { Kolmogorov- } \\
\text { Smirnova }\end{array}$} & \multicolumn{3}{|c|}{ Shapiro-Wilk } \\
\cline { 2 - 8 } & $\begin{array}{l}\text { Stati } \\
\text { s tic }\end{array}$ & df & Sig. & $\begin{array}{l}\text { Stati } \\
\text { s tic }\end{array}$ & df & Sig. \\
\hline \multirow{2}{*}{$\begin{array}{l}\text { Ni } \\
\text { lai }\end{array}$} & VA &, 178 & 16 &, 188 &, 897 & 16 &, 072 \\
\cline { 3 - 8 } & VB &, 243 & 19 &, 004 &, 906 & 19 &, 063 \\
\hline
\end{tabular}
a. Lilliefors Significance Correction

Berdasarkan Tabel 2 nilai signifikan yang diperoleh pada keterangan kolom shapiro-wilk pada 0,072 kelas eksperimen dan 0,063 pada kelas kontrol > 0,05 (taraf tingkat kesalahan/ penolakan), maka dapat dikatakan bahwa data hasil belajar materi daur air dan kegiatan manusia yang mempengaruhinya berdistribusi normal.

\section{b. Uji Homogenitas}

Hasil uji homogenitas dapat dilihat pada Tabel berikut ini:

Tabel 5. Hasil Uji Homogenitas Kelas Sampel

\begin{tabular}{|r|r|r|r|}
\hline $\begin{array}{l}\text { Levene } \\
\text { Statistic }\end{array}$ & df1 & \multicolumn{1}{|c|}{ df2 } & \multicolumn{2}{|c|}{ Sig. } \\
\hline 1,691 & 1 & 33 &, 202 \\
\hline
\end{tabular}

Berdasarkan Tabel 5 nilai signifikan yang diperoleh yaitu $0,202>0,05$ (taraf tingkat kesalahan/penolakan) maka dapat 
dikatakan bahwa data hasil belajar materi daur air dan kegiatan manusia yang mempengaruhinya berdistribusi homogen.

\section{PengujianHipotesis}

Hasil uji-t pada kedua kelas sampel dapat dilihat pada table di bawah ini:

Tabel 6. Hasil Uji Hipotesis Hasil Belajar Materi Daur Air dan Kegiatan Manusia yang Mempengaruhinya Sampel

\begin{tabular}{lcccccc} 
Kelas & $\mathbf{N}$ & $\overline{\boldsymbol{X}}$ & $\mathbf{S}$ & $\begin{array}{c}\mathbf{t}_{\text {hit }} \\
\text { ung }\end{array}$ & $\mathbf{t}_{\text {Tabel }}$ & $\alpha$ \\
Sampel & & & & & \\
Eksperi & 16 & 86,3 & 8,9 & 1,92 & 1,69 & 0,05 \\
men & & & & & 2 & \\
\cline { 1 - 3 } Kontrol & 19 & 81,3 & 6,9 & & & \\
\end{tabular}

Berdasarkan Tabel 6 hasil uji hipotesis dengan metode uji- $t$ secara manual maka diperolehlah data nilait hitung $=1,9252$ dan $t_{\text {tabel }}=1,692$, dimana $t_{\text {hitung }}$ lebih besar dari pada $t_{\text {tabel }}$. Maka dapat diartikan bahwa $H_{0}$ ditolak dan $H_{1}$ diterima yang berbunyi "terdapa pengaruh pendekatan konstruktivisme terhadap hasil belajar IPA di kelas V SD N 33 Kota Padang".

\section{B. Pembahasan}

Berdasarkan pada analisis data yang telah didapatkan, maka terlihat bahwa ada pengaruh hasil belajar peserta didik pada kelas eksperimen yang belajar dengan menggunakan pendekatan konstruktivisme dengan peserta didik kelas kontrol yang menggunakan pembelajaran konvensional. Hal ini dapat dilihat dari nilai rata-rata peserta didik kelas eksperimen 86,3 dan kelas kontrol 81,3. Pendekatan konstruktivisme adalah salah satu pendekatan pembelajaran yang dapat mempengaruhi hasil belajar peserta didik. Hal tersebut dapat dilihat dari hasil uji hipotesis dengan menggunakan uji-t. Dari hasil perhitungan diperoleh bahwa tolak $\mathrm{H}_{0}$ karena diperoleh $\mathrm{t}_{\text {hitung }}=1,9252$ lebih besar dari $t_{\text {Tabel }}=1,696$. Sehingga dapat disimpulkan tolak $\mathrm{H}_{0}$ dan terima $\mathrm{H}_{1}$, dengan kata lain "terdapat pengaruh penggunaan pendekatan konstruktivisme terhadap hasil belajar IPA di kelas V SDN 33 Kalumbuk Kota Padang”.

Berdasarkan hasil post-test, penggunaan pendekatan konstruktivisme cocok diterapkan untuk mempengaruhi hasil belajar peserta didik. Hal ini sesuai yang dikemukakan oleh Rosalin (2008:15) "Pendekatan konstruktivisme merupakan pendekatan belajar yang 
dapat dikembangkan terhadap peserta didik. Pendekatan konstruktivisme dimulai dengan adanya pengetahuan awal peserta didik, kemudian peserta didik dihadapkan pada keadaan lain yang menimbulkan konflik di dalam pikiran peserta didik.

Pembelajaran dengan pendekatan konstruktivisme memiliki daya tarik tersendiri dan dapat menjadi pemicu atau memotivasi peserta didik untuk belajar IPA. Peserta didik lebih terfokus dalam mengikuti pelajaran karena mengamati langsung tentang proses, situasi atau benda tertentu yang sedang dipelajari sehingga pembelajaran yang dialami peserta didik lebih bermakna, serta kesalahan-kesalahan yang terjadi dapat diatasi melalui pengamatan dan contoh konkrit. Jadi, pembelajaran IPA pada materi daur dan kegiatan manusia yang mempengaruhinya dengan menggunakan pendekatan konstruktivisme berpengaruh terhadap hasil belajar peserta didik agar hasil belajar menjadi lebih meningkat.

Proses pembelajaran yang dilakukan menggunakan pendekatan konstruktivisme di kelas eksperimen dan pembelajaran konvensional di kelas kontrol, dapat dipahami bahwa kedua metode tersebut memiliki pengaruh yang berbeda dalam meningkatkan kemampuan kognitif dan hasil belajar peserta didik. Pengaruh yang ditimbulkan dari pendekatan konstruktivisme lebih baik dibandingkan ceramah dan tanya jawab. Hal tersebut sesuai dengan pendapat Hanbury (dalam buku Suyono dan Hariyanto, (2013:108109), mengatakan kelebihan dari pendekatan konstruktivisme yaitu: “(1) peserta didik mengkonstruksi pengetahuan dengan cara mengintegrasikan ide yang mereka miliki, (2) pembelajaran lebih bermakna karena peserta didik mengerti, (3) strategi peserta didik sendiri lebih bernilai, dan (4) peserta didik mempunyai kesempatan untuk berdiskusi dan saling bertukar pengalaman dan pengetahuan dengan temannya”. Dengan demikian peserta didik akan cepat mengingat pembelajaran yang dipelajari melalui pengamatan langsung serta dapat membandingkan teori dengan kenyataan. 


\section{KESIMPULAN}

Dari hasil penelitian terbukti bahwa penggunaan pendekatan konstruktivisme memberikan pengaruh terhadap hasil terhadap hasil belajar IPA di kelas V SDN 33 Kalumbuk Kota Padang.

\section{DAFTAR PUSTAKA}

Haerunisa, Siti Rahma. 2008. Pengaruh Pembelajaran Konstruktivisme dalam Pembelajaran Kimia Terhadap Pemahaman Peserta didik Tentang Sistem Koloid. Skripsi. UIN Jakarta.

Jasumayanti, Eka. 2013. Korelasi Antara Pendekatan Konstruktivisme dengan Hasil Belajar Peserta didik pada Pembelajaran IPS SD. Jurnal Penelitian Pendidikan Univesitas Negeri Yogyakarta. (Diaksespada 28 Oktober 2015, pukul 19.95 WIB).

Muhammad, Hasan. 2012. Penerapan model Pembelajaran Konstruktivisme untuk Meningkatkan Pemahaman Peserta didik Mengenai Energi Gerak di Kelas III SD Negeri 1 Cilengkranggirang Kecamatan Pasaleman Kabupaten Cirebon. Skripsi.

Priyatno Duwi. 2010. Paham Analisa Statistik Data dengan SPSS. Yogyakarta: Mediakom.
Rosalin, Elin. 2008. Gagasan Merancang Pembelajaran Konstektual. Bandung: Karsa Mandiri Persada.

Sanjaya, Wina. 2010. Kurikulum dan Pembelajaran. Jakarta: Kencana.

Suyono dan Hariyanto. 2013. Belajar dan Pembelajaran: Teori dan Konsep Dasar. Bandung: PT Remaja Rosda karya.

Suwangsih, Erna dan Taulina. 2006. Model Pembelajaran Matematika. Bandung: UPI Press.

Sugiyono. 2011. Metode Penelitian Pendidikan (Pendekatan Kuantitatif, Kuliatatif, dan $R \& D)$. Bandung: Alfabeta.

Trianto. 2014. Model Pembelajaran Terpadu. Jakarta: PT Bumi Aksara. 